\title{
Pre-service Teachers' Perceptions about Self-efficacy Factors to Teaching in Delta State, Nigeria
}

\author{
Akporehe Dorah A, Nkedishu Victor Chukwubueze* \\ Department of Educational Management and Foundations, Delta State University, Abraka, Nigeria
}

Received October 9, 2020; Revised November 13, 2020; Accepted December 11, 2020

\section{Cite This Paper in the following Citation Styles}

(a): [1] Akporehe Dorah A, Nkedishu Victor Chukwubueze, "Pre-service Teachers' Perceptions about Self-efficacy Factors to Teaching in Delta State, Nigeria," Universal Journal of Educational Research, Vol. 8, No. 12A, pp. 7521 7529, 2020. DOI: 10.13189/ujer.2020.082536.

(b): Akporehe Dorah A, Nkedishu Victor Chukwubueze (2020). Pre-service Teachers' Perceptions about Self-efficacy Factors to Teaching in Delta State, Nigeria. Universal Journal of Educational Research, 8(12A), 7521 - 7529. DOI: 10.13189/ujer.2020.082536.

Copyright $\odot 2020$ by authors, all rights reserved. Authors agree that this article remains permanently open access under the terms of the Creative Commons Attribution License 4.0 International License

\begin{abstract}
The purpose of this study was to examine pre-service teachers' perceptions about self-efficacy factors to teaching in Delta State, Nigeria. Ex-post-facto research design was adopted while purposive sampling technique was utilized to select 453 respondents from participants of 2265 final year degree students from Colleges of education in Delta State. Questionnaire, titled "Pre-service Teachers Perceptions about Self- Efficacy Factors to Teaching Questionnaire (PTPSFTQ)" was utilized in obtaining information from participants. Data analysis was carried out with descriptive statistics and inferential statistics at .05 level of significance. Findings show that pre-service teachers' perceptions about self-efficacy factors to teaching include; teaching profession is a worthy career, teachers are respectable members of the society, they will take up teaching profession when they graduate, among others. Also, measures such as; making students see teaching as part of their daily life, showing students the relevance of teaching to their future careers and allowing students to participate in the whole process of teaching could be used to improve pre-service teachers' self-efficacy factors to teaching. Recommendation, there should be proper orientation for students with special interest on self-efficacy factors to teaching.
\end{abstract}

Keywords Pre-service Teachers, Perceptions, Self-efficacy Factors, Teaching, Delta State

\section{Introduction}

In human civilization, teaching profession is a noble vocation which may require adequate planning for personnel that wish to undergo the profession. Efficacy of people who wish to go into the job should be of great concern to stakeholders in education. It seems that efficacy in teaching profession is fast becoming an issue and may generate some researches such as Bandura [1] who asserted that self-efficacy beliefs play an imperative role in initial learning and that, once established, are resistant to change; it is essential to gather the entry levels of educator self-efficacy opinions for future beginning teachers. Protheroe [2] explained teachers' efficacy as teachers' confidence in their ability to promote students' learning. It can be said to be a quality of self-belief in the ability to perform an action to achieve a goal. A research on pre-service teacher efficacy is therefore vital in a quest to having quality teachers in educational institutions especially at secondary school level.

Pre-service teachers are referred to as students undergoing education studies in recognized higher institutions of learning where courses in education are offered. These sets of individuals are potential human resource in the secondary education. As a result of this, stakeholders may be worried about the crop of teachers, which will eventually be recruited to teach in the secondary school system. According to Ryan; Young and Kraglund-Gauthier [3], pre-service is an inspiring experience that involves application of theory into practice, 
or praxis, as pre-service educators alter and build identities within often unacquainted, fast-paced, and strong practicum environments. Pre-service teacher training is a period for all to think upon area of specialization while confronting, overcoming predicaments that surfaces in pre-service training [3].

The educational system especially secondary school needs transformational teachers and it is only those teachers who exhibit high efficacy that are expected to be able to make transformational learning take place on the learners. Teachers may have different notions about teaching profession, which if bring to bear in the working place could mare their dedication to the teaching profession. For instance, the issue of automatic promotion for teachers at the end of three years could make teachers not update or upgrade their teaching skills. This could be the reason why Mezirow [4], stated that fixed interpersonal relationships; political orientations; cultural bias; ideologies; schemata; stereotyped conducts and practices; mind occupational habits; doctrine; moral-ethical norms; psychological choices and schema; paradigms in mathematics/sciences; frames in social sciences and linguistics; and aesthetic values were taken for granted.

\section{Literature Review}

For secondary education in Nigeria to attain its stated goals, there is need for search to light on issues of efficacy of pre-service teachers in an attempt to produce quality teachers for secondary school educational system. While attainment of excellence in academic is shown in performances in examination as depicted by scores which could be deemed to be yardstick for qualification to teach, the actual performance in the field is a different ball game as job description bothering oneself-efficacy will come to play. Protheroe [2] maintained that, it is not enough to hire and retain the brightest teachers, they must also believe they can successfully cope with challenges of the work at hand. Hence, Lunenburg [5], opined that organizations should select individuals who have high levels of self-efficacy as those people will be motivated to engage in the behaviours that will help them achieve their duties. From this point, people with a good measure of self-efficacy should be the ones to be admitted to study teacher education programme.

Lunenburg [5] maintained that supervisors can enhance self-efficacy by hiring, providing stimulating assignments, capacity building and coaching, leadership, goal setting, and rewards for enhancement. Supporting the above, Pendergast, Garvis and Keogh, [6] stressed that teacher self-efficacy will be maintained when teacher educators, school leaders and policy makers would need to reconsider the support needed for retaining beginning teachers by promoting resilient and sustained teacher self-efficacy beliefs. Self-efficacy is therefore a special quality of a pre-service teacher. Dahar et. al. [7] conducted a study on teacher quality and students' academic achievement. The authors found that quantity of academic and professional degrees, trainings, years of service, nor amount of salary were not significant but attitude of teachers towards teaching and the extent of the use of their skills, expertise and abilities in teaching that were important. Pendergast, Garvis and Keogh [6] maintained that teachers with high level of self-efficacy have been discovered to be more irrepressible in their teaching and probable attempt harder to assist all students reach their potential. They also noted conversely that teachers with low level of self-efficacy have been found to be less prospective to try harder and reach the learning needs of all their students. This is why pre-service teacher self-efficacy has to be determined at the point of entering the teaching field.

Pendergast, Garvis \& Keogh, [6] study of Graduate Diploma Education Programmes (GDEP) of one year on teacher phase of initial entry into teacher education programmes, where pre-service teachers enter teacher education and have no previous practical teaching experience and limited exposure to teacher education programmes; and at the end of the pre-service teacher training programme revealed change in teacher self-efficacy during the duration of one study. The different stages produced different self-efficiency levels with beginning teachers showing initially higher levels of teacher self-efficacy towards perceived capabilities of teaching and a decline in teacher self-efficacy between the commencement and conclusion of programs. This goes to show that perceptions and impressions as well as preconceived ideas if not well addressed and managed could influence self-confidence and performances on the job.

Issues bothering on work environment could be corrected or remedied by management and government, but if a teacher takes wrong impression to the job, the students will suffer for it as this boils down to self-efficacy factors of the teacher. Self-motivation and self-satisfaction are encapsulated in teacher efficacy. Determining self-efficacy factors will help to know who is actually interested on the job and educational planners could fashion out model for re-orientation of the students' mind-set towards the job they are about to venture into. Teacher self-efficacy factors can be ingrained into teacher education programme for efficiency in the teaching profession.

Outcome expectancy and self-efficacy were human behaviour which are motivated by interaction of two types of expectations [8]. Based on individual perception, self-efficacy is the competence to undertake and accomplish successfully a precise task in an exact context, while outcome expectancy is judgments about the possible penalties that can result from self-efficacy. Teachers' 
disposition towards teaching is expected to be a positive one so that the learner will be motivated to learn. Teachers' attitude towards the learner creates a permanent imprint in their mind and could affect their decisions and actions in life. This view was shared by Lindquist and Lindquist [9] who opined that it is necessary that a pre-service education program to break assumptions that have been ingrained in the thought patterns of pre-service teachers through personal experience, replacing them with highly toned teaching skills and parallel professional disposition. Therefore pre-service preparation has a great role in determining self-efficacy. Pendergast, Garvis and Keogh [6] revealed that programme, age and gender were characteristics which were not revealed to be scientifically related to self-efficacy of pre-service participants. On the other hand, study of Sonfo, Amankwah, Sam and Konin [10] shows that teachers' self-efficacy beliefs; relationship between gender and classroom management, instructional strategies, and student engagement discovered that male teachers differ from female teachers in relation to their instructional strategy efficacy beliefs with females having higher instructional efficacy beliefs. Atomatofa [11] established that male teachers have positive self-efficacy beliefs about school climate and their effectiveness to influence school resources, instructional self-efficacy, efficacy to influence parental and community involvement, and efficiency to create positive learning climate. While the female teachers' have positive self-efficacy to influence school resources, influence discipline and parental decision.

Ahmad and Tamiz [12] study on impact of teacher self-efficacy on students' motivation and achievement indicated that there is a positive correlation between teachers' self-efficacy and motivation and achievement of students. Tournaki and Podell [13] study on impact of student characteristics and teacher efficacy on teachers' predictions of student success conducted on three hundred and eighty-four general education teachers specified that teachers with high efficiency made fewer negative forecasts about students and appeared to adjust their forecasts when student features changed, while little efficacy teachers appeared to pay attention to single characteristic when casting their predictions. Hence Adeyemi [14] maintained that many dropouts were victims of hostile school environments, to the extent that many of the students saw the school as a grim joyless place with petty oppressive demands, rules and regulations and by implication, internal efficiency of schools.

\section{Theoretical Framework}

The research anchors on Social Cognitive Theory of Bandura [15] that emphasizes on major role of cognition in encoding and performing behaviours. The theory argued that human behaviour is caused by personal, behavioural, and environmental influences. It went further to stress that self-efficacy is "the belief in one's capabilities to organize and execute the courses of action required to manage prospective situations. This view is worth noting as pre-service teachers are likely to have varying self-efficacy arising, especially from behavioural and environmental influences perceived in the social cultural milieu. For pre-service teachers whose self-efficacy could be managed, building positive structures are necessary for the educational system to stem bringing bad behaviour to bear in the school system particularly in the event of being employed to teach. Determining self-efficacy of pre-service teacher education students is a sure way of planning for and ensuring quality assurance in the educational system. Self-efficacy factors are also important in teacher recruitment process. Ahmad and Tamiz [12] had entertained fear that it seems that personality testing is lagging behind in education compared to the other disciplines, noting that in teacher recruitment, personality testing is either totally neglected, or there is just a subjective evaluation of applicants' personality.

\section{Statement of the Problem}

Having teachers with high self-efficacy will go a long way in achieving educational goals and it is a key productive indicator in teaching profession. It seems that pre-service teachers do not exhibit interest in the teaching profession; newly recruited teachers also perform their jobs as if the career is of no worth, while experienced ones complain about disposition of teachers especially newly recruited to their duty. In the same vein, pre-service teachers on practicum often display attitudes and disposition that portray disinterest on the job. These attitudes will no doubt lead to malfunctioning of the school system with the resultant effect of failure as well as dropouts of students. Therefore, identifying pre-service teachers' self-efficacy factors to teaching is the concern of this study.

\section{Purpose of the Study}

The purpose of this study was to examine pre-service teachers' perceptions about self-efficacy factors to teaching in Delta State, Nigeria; suggest measures to improve pre-service teachers' self-efficacy factors to teaching and determine gender opinion on pre-service teachers' self-efficacy factors to teaching.

\section{Significance of the Study}

The study is significant as it will help in the following ways: in selection of students into teacher education programme in colleges of education universities affiliate institutions; reconfigure the delivery of teacher education 
activities to mould the individual into a reconstructed person with greater value of the teaching profession. It will help policy makers in decision of teacher recruitment and selection in public institutions as the aptitude for the job can be known

\section{Research Questions}

1. What are the mean ratings of pre-service teachers' self-efficacy factors to teaching in affiliate university degree education programme in colleges of education in Delta state?

2. What measures can be used to improve self-efficacy factors of pre-service teachers to teaching in affiliate university degree education programme in colleges of education in Delta state?

3. Is there a difference between mean ratings of male and female pre-service teachers on self-efficacy factors to teaching in affiliate university degree education programme in colleges of education in Delta state?

\section{Hypothesis}

1. Mean ratings of male and female pre-service teachers are not significantly different to self-efficacy factors to teaching in affiliate university degree education programme in colleges of education Delta state.

\section{Method}

\section{Study Design}

The ex-post-facto research design was adopted for this study. This design assisted in establishing pre-service teachers on self-efficacy factors to teaching as it has occurred and cannot be manipulated.

\section{Participants}

Participants of the study consist of 2265 final year Degree students from Colleges of education in Delta State who are affiliated to Delta State University and are regarded as pre-service teachers. The participants were from public institution. These institutions affiliated to Delta State University include; College of Education
Agbor, College of Physical and Health Education Mosogar, and College of Education Warri. Purposive sampling technique was used to select 453 respondents representing $20 \%$ of the entire population.

\section{Instrument}

The research instrument was self-structured questionnaire, titled "Pre-service Teachers Perceptions about Self- Efficacy Factors to Teaching Questionnaire (PTPSFTQ)" in which respondents were required to respond in 5-point Likert scale of strongly agree $=5$, agree $=4$ undecided $=3$, disagree $=2$ and strongly disagree $=1$ respectively. The instrument was an adaptation of Ohio State Teacher Efficacy Scale (OSTES). The OSTES is a product of synthesis of several instruments of researchers to fully explain the construct of self-efficacy of teachers. The instrument was used to solicit responses from the degree pre-service teachers of affiliate programmes in Delta State.

\section{Validity and Reliability of the Instrument}

The instrument was validated by experts in test construction through face and content validity. Test retest method was used to test the reliability of the instrument and Pearson $r$ was used to establish the correlation which stood at .73 index.

\section{Data Analysis}

Data analysis was carried out with descriptive statistics of mean rating and standard deviation (SD) with a benchmark mean rating of 3.00, this implies that any item with mean rating of 3.00 and above is agree, any mean rating below 3.00 is disagree. While hypothesis was tested using inferential statistics of t-test at .05 level of significance.

\section{Findings}

Research Question 1: What are the mean ratings of pre-service teachers' self-efficacy factors to teaching in affiliate university degree education programme in colleges of education in Delta state? 
Table 1. Mean rating and SD on pre-service teachers' self-efficacy factors to teaching

\begin{tabular}{|c|c|c|c|c|}
\hline $\mathbf{S} / \mathbf{N}$ & Self-Efficacy Factors & Mean & SD & Remark \\
\hline 1 & Teaching profession is a worthy career & 3.50 & 1.63 & Agree \\
\hline 2 & Teachers are respectable members of the society & 3.31 & 1.40 & Agree \\
\hline 3 & The glory of the teaching profession has gone & 2.68 & 1.44 & Disagree \\
\hline 4 & I have to read education because I had no other option & 2.40 & 1.46 & Disagree \\
\hline 5 & I will take up teaching profession when I graduate & 3.36 & 1.45 & Agree \\
\hline 6 & Education courses are interesting & 3.78 & 1.39 & Agree \\
\hline 7 & I am proud to introduce myself as a would-be teacher & 3.53 & 1.42 & Agree \\
\hline 8 & I can encourage someone to take education course as a career & 3.61 & 1.43 & Agree \\
\hline 9 & Teaching practice is an enjoyable period to me & 3.74 & 1.37 & Agree \\
\hline 10 & Teaching profession is for poor people & 1.90 & 1.42 & Disagree \\
\hline 11 & Teaching profession is for dull students & 1.50 & 1.09 & Disagree \\
\hline 12 & Teaching courses demand too much financially & 2.41 & 1.39 & Disagree \\
\hline 13 & Teachers usually live below average standard of living & 2.52 & 1.48 & Disagree \\
\hline 14 & I am satisfied with the career I am going into & 3.82 & 1.43 & Agree \\
\hline 15 & The society looks down on teachers & 3.33 & 1.55 & Agree \\
\hline 16 & I find my course of study interesting & 3.92 & 1.39 & Agree \\
\hline 17 & Teaching practice is interesting & 3.81 & 1.49 & Agree \\
\hline 18 & Education courses are for non-intelligent students & 1.66 & 1.21 & Disagree \\
\hline 19 & There is less competition for admission into teacher education programmes & 2.79 & 1.46 & Disagree \\
\hline 20 & Teaching profession allows time for private business & 3.62 & 1.49 & Agree \\
\hline 21 & I am reading education just to possess a certificate. & 2.25 & 1.39 & Disagree \\
\hline 22 & Teaching profession is an all-comer's profession & 2.70 & 1.45 & Disagree \\
\hline 23 & The society appreciates teachers & 3.09 & 1.50 & Agree \\
\hline 24 & Teaching does not provide for professional development of teachers & 3.53 & 1.47 & Agree \\
\hline 25 & Teachers' salary is commensurate with the task involved & 2.42 & 1.43 & Disagree \\
\hline 26 & School management is optimistic about pre-service teachers & 2.65 & 1.55 & Disagree \\
\hline 27 & Teachers are well cared for by the government. & 2.62 & 1.44 & Disagree \\
\hline 28 & Pre-service teachers are well mentored in school & 2.31 & 1.40 & Disagree \\
\hline 29 & Students show enthusiasm to learn & 2.88 & 1.45 & Disagree \\
\hline 30 & Teachers show laisse faire attitude towards teaching & 3.18 & 1.40 & Agree \\
\hline 31 & I would work anywhere I am posted to as a teacher & 2.92 & 1.48 & Disagree \\
\hline 32 & Marking is a difficult moment for me & 3.20 & 1.49 & Agree \\
\hline 33 & School environments are pleasant to me & 2.41 & 1.42 & Disagree \\
\hline 34 & I teach only when students are prepared to learn & 3.20 & 1.44 & Agree \\
\hline 35 & 1 enjoy working with learners & 2.88 & 1.45 & Disagree \\
\hline 36 & Practicum is mere formalities & 2.44 & 1.46 & Disagree \\
\hline 37 & Working in school environments is satisfying to me & 2.38 & 1.45 & Disagree \\
\hline 38 & Practicum teaching is a waste of time & 3.31 & 1.44 & Agree \\
\hline 39 & Teacher education institution prepares adequately for classroom management & 2.17 & 1.38 & Disagree \\
\hline 40 & Older teachers show good examples & 3.75 & 1.51 & Agree \\
\hline
\end{tabular}

Data in Table 1 shows mean ratings of pre-service teachers' self-efficacy factors to teaching. Result shows that respondents attested to items $1,2,5,6,7,8,9,14,15$,
$16,17,20,23,24,30,32,34,38$ and 40 with mean rating above 3.00 , but disagreed on items $3,4,10,11,12,13,18$, $19,21,22,25,26,27,28,29,31,33,35,36,37$ and 39 
with mean rating below 3.00. Conclusively, pre-service teachers' perceptions about self-efficacy factors to teaching include; teaching profession is a worthy career, teachers are respectable members of the society, they will take up teaching profession when they graduate, education courses are interesting, they are proud to introduce myself as awould-be teacher, they can encourage someone to take education course as a career, teaching practice is an enjoyable period to me, they are satisfied with the career they going into, the society looks down on teachers, they find my course of study interesting, teaching practice is interesting, teaching profession allows time for private business, the society appreciates teachers, teaching does not provide for professional development of teachers, teachers show laisse faire attitude towards teaching, marking is a difficult moment for me, they teach only when students are prepared to learn, practicum teaching is a waste of time and older teachers show good examples.

Research Question 2: What measures can be used to improve self-efficacy factors of pre-service teachers to teaching in affiliate university degree education programme in colleges of education in Delta state?

Data in Table 2 show on mean rating and SD on measures to improve self-efficacy factors of pre-service teachers to teaching. Result revealed that respondents agreed on all items with mean rating above benchmark mean rating of 3.00. Thus, measures such as; make students see teaching as part of their daily life, show students the relevance of teaching to their future careers, allow students to participate in the whole process of teaching, use multiple resources in teaching, apply methods that will make teaching fun, relate teaching to real life situation, make learning environment attractive, teach students from simple to complex, understand students interest to the course of study and admit students who have passion for teaching can be used to improve self-efficacy factors of pre-service teachers to teaching.
Table 2. Mean rating and SD on measures to improve self-efficacy factors of pre-service teachers to teaching

\begin{tabular}{|c|c|c|c|c|}
\hline $\mathbf{S} / \mathbf{N}$ & $\begin{array}{c}\text { Measures to improve } \\
\text { self-efficacy }\end{array}$ & Mean & SD & Remark \\
\hline 1 & $\begin{array}{c}\text { Make students to see } \\
\text { teaching as part of their daily } \\
\text { life }\end{array}$ & 3.50 & 1.63 & Agree \\
\hline 2 & $\begin{array}{c}\text { Show students the relevance } \\
\text { of teaching to their future } \\
\text { careers }\end{array}$ & 3.31 & 1.40 & Agree \\
\hline 3 & $\begin{array}{c}\text { Allow students to participate } \\
\text { in the whole process of } \\
\text { teaching }\end{array}$ & 3.68 & 1.44 & Agree \\
\hline 4 & $\begin{array}{c}\text { Use multiple resources in } \\
\text { teaching }\end{array}$ & 3.40 & 1.45 & Agree \\
\hline 5 & $\begin{array}{l}\text { Apply methods that will } \\
\text { make teaching fun }\end{array}$ & 3.26 & 1.46 & Agree \\
\hline 6 & $\begin{array}{l}\text { Relate teaching to real life } \\
\text { situation }\end{array}$ & 3.18 & 1.40 & Agree \\
\hline 7 & $\begin{array}{c}\text { Make learning environment } \\
\text { attractive }\end{array}$ & 3.33 & 1.42 & Agree \\
\hline 8 & $\begin{array}{l}\text { Teach students from simple } \\
\text { to complex }\end{array}$ & 3.51 & 1.44 & Agree \\
\hline 9 & $\begin{array}{c}\text { Understand students' interest } \\
\text { to the course of study }\end{array}$ & 3.64 & 1.37 & Agree \\
\hline 10 & $\begin{array}{l}\text { Admit students who have } \\
\text { passion for teaching }\end{array}$ & 3.90 & 1.45 & Agree \\
\hline
\end{tabular}

Research Question 3: Is there a difference between mean ratings of male and female pre-service teachers on self-efficacy factors to teaching in affiliate university degree education programme in colleges of education in Delta state?

Data in Table 3 show mean rating and SD on difference between mean ratings of male and female pre-service teachers on self-efficacy factors to teaching. Results revealed an average mean rating of $2.91, \mathrm{SD}=43$ and 2.93 , $\mathrm{SD}=1.43$ for male and female students respectively. These mean rating shows that there is no difference between mean ratings of male and female pre-service teachers on self-efficacy factors to teaching, since both mean ratings did not exceed the benchmark mean rating of 3.00. 
Table 3. Mean rating and SD on difference between mean ratings of male and female pre-service teachers on self-efficacy factors to teaching

\begin{tabular}{|c|c|c|c|c|c|c|c|}
\hline \multirow{2}{*}{$\mathbf{S} / \mathbf{N}$} & \multirow{2}{*}{ Self-Efficacy Factors } & \multicolumn{3}{|c|}{ Male $=201$} & \multicolumn{3}{|c|}{ Female $=\mathbf{2 5 2}$} \\
\hline & & $\mathbf{M}$ & SD & $\mathbf{R}$ & $\mathbf{M}$ & SD & $\mathbf{R}$ \\
\hline 1 & Teaching profession is a worthy career & 3.26 & 1.65 & A & 3.65 & 1.57 & A \\
\hline 2 & Teachers are respectable members of the society & 3.15 & 1.34 & A & 3.43 & 1.43 & A \\
\hline 3 & The glory of the teaching profession has gone & 2.84 & 1.41 & $\mathrm{D}$ & 2.51 & 1.44 & $\mathrm{D}$ \\
\hline 4 & I have to read education because I had no other option & 2.56 & 1.51 & $\mathrm{D}$ & 2.28 & 1.40 & $\mathrm{D}$ \\
\hline 5 & I will take up teaching profession when I graduate & 3.35 & 1.41 & A & 3.37 & 1.47 & A \\
\hline 6 & Education courses are interesting & 3.68 & 1.37 & A & 3.85 & 1.38 & A \\
\hline 7 & I am proud to introduce myself as a would-be teacher & 3.33 & 1.36 & A & 3.69 & 1.42 & A \\
\hline 8 & I can encourage someone to take education course as a career & 3.33 & 1.49 & A & 3.83 & 1.34 & A \\
\hline 9 & Teaching practice is an enjoyable period to me & 3.57 & 1.37 & A & 3.91 & 1.31 & A \\
\hline 10 & Teaching profession is for poor people & 2.05 & 1.46 & $\mathrm{D}$ & 1.82 & 1.39 & $\mathrm{D}$ \\
\hline 11 & Teaching profession is for dull students & 1.61 & 1.18 & $\mathrm{D}$ & 1.42 & 1.02 & $\mathrm{D}$ \\
\hline 12 & Teaching courses demand too much financially & 2.58 & 1.43 & $\mathrm{D}$ & 2.25 & 1.33 & $\mathrm{D}$ \\
\hline 13 & Teachers usually live below average standard of living & 2.53 & 1.42 & $\mathrm{D}$ & 2.50 & 1.51 & $\mathrm{D}$ \\
\hline 14 & I am satisfied with the career I am going into & 3.60 & 1.52 & A & 4.02 & 1.34 & A \\
\hline 15 & The society looks down on teachers & 3.42 & 1.49 & A & 3.24 & 1.61 & A \\
\hline 16 & I find my course of study interesting & 3.81 & 1.39 & A & 4.01 & 1.39 & A \\
\hline 17 & Teaching practice is interesting & 3.60 & 1.52 & A & 4.01 & 1.41 & A \\
\hline 18 & Education courses are for non-intelligent students & 1.75 & 1.19 & $\mathrm{D}$ & 1.58 & 1.21 & $\mathrm{D}$ \\
\hline 19 & $\begin{array}{l}\text { There is less competition for admission into teacher education } \\
\text { programmes }\end{array}$ & 2.83 & 1.41 & $\mathrm{D}$ & 2.74 & 1.49 & $\mathrm{D}$ \\
\hline 20 & Teaching profession allows time for private business & 3.37 & 1.48 & A & 3.83 & 1.47 & A \\
\hline 21 & I am reading education just to possess a certificate. & 2.49 & 1.44 & $\mathrm{D}$ & 2.06 & 1.30 & $\mathrm{D}$ \\
\hline 22 & Teaching profession is an all-comer's profession & 2.70 & 1.44 & $\mathrm{D}$ & 2.17 & 1.48 & $\mathrm{D}$ \\
\hline 23 & The society appreciates teachers & 2.89 & 1.47 & $\mathrm{D}$ & 3.24 & 1.52 & A \\
\hline 24 & Teaching does not provide for professional development of teachers & 3.40 & 1.40 & A & 3.62 & 1.51 & A \\
\hline 25 & Teachers' salary is commensurate with the task involved & 2.45 & 1.42 & $\mathrm{D}$ & 2.39 & 1.43 & $\mathrm{D}$ \\
\hline 26 & School management is optimistic about pre-service teachers & 2.71 & 1.61 & $\mathrm{D}$ & 2.57 & 1.49 & $\mathrm{D}$ \\
\hline 27 & Teachers are well cared for by the government. & 2.63 & 1.35 & $\mathrm{D}$ & 2.66 & 1.50 & $\mathrm{D}$ \\
\hline 28 & Pre-service teachers are well mentored in school & 2.40 & 1.39 & $\mathrm{D}$ & 2.23 & 1.40 & $\mathrm{D}$ \\
\hline 29 & Students show enthusiasm to learn & 2.92 & 1.41 & $\mathrm{D}$ & 2.86 & 1.50 & $\mathrm{D}$ \\
\hline 30 & Teachers show laisse faire attitude towards teaching & 3.31 & 1.32 & A & 3.07 & 1.46 & A \\
\hline 31 & I would work anywhere I am posted to as a teacher & 3.01 & 1.47 & A & 2.87 & 1.49 & $\mathrm{D}$ \\
\hline 32 & Marking is a difficult moment for me & 3.01 & 1.50 & A & 3.32 & 1.46 & A \\
\hline 33 & School environments are pleasant to me & 2.47 & 1.40 & $\mathrm{D}$ & 2.37 & 1.44 & $\mathrm{D}$ \\
\hline 34 & I teach only when students are prepared to learn & 3.06 & 1.39 & A & 3.31 & 1.47 & A \\
\hline 35 & 1 enjoy working with learners & 2.69 & 1.43 & $\mathrm{D}$ & 2.19 & 1.47 & $\mathrm{D}$ \\
\hline 36 & Practicum is mere formalities & 2.53 & 1.44 & $\mathrm{D}$ & 2.39 & 1.49 & $\mathrm{D}$ \\
\hline 37 & Working in school environments is satisfying to me & 2.49 & 1.40 & $\mathrm{D}$ & 2.31 & 1.48 & $\mathrm{D}$ \\
\hline 38 & Practicum teaching is a waste of time & 3.15 & 1.41 & A & 3.44 & 1.44 & A \\
\hline 39 & $\begin{array}{c}\text { Teacher education institution prepares adequately for classroom } \\
\text { management }\end{array}$ & 2.16 & 1.32 & $\mathrm{D}$ & 2.19 & 1.44 & $\mathrm{D}$ \\
\hline 40 & Older teachers show good examples & 3.59 & 1.57 & A & 3.90 & 1.44 & A \\
\hline & Average mean rating & 2.91 & 1.43 & $\mathrm{D}$ & 2.93 & 1.43 & $\mathrm{D}$ \\
\hline
\end{tabular}

Keys: $\mathrm{M}=$ Mean, $\mathrm{SD}=$ Standard Deviation, $\mathrm{R}=$ Remark, $\mathrm{A}=$ Agree, $\mathrm{D}=$ Disagree 
Table 4. t-test summary on mean ratings of male and female on pre-service teachers' self-efficacy factors to teaching

\begin{tabular}{|c|c|c|c|c|c|c|c|c|}
\hline Variables & Number & Mean & SD & Df & Sign. & t-crit. & t-cal. & Decision \\
\hline Male Students & 201 & 2.91 & 1.43 & \multirow{2}{*}{451} & \multirow{2}{*}{.05} & \pm 1.96 & \multirow{2}{*}{.088} & \multirow{2}{*}{ Not significant } \\
\hline Female Students & 252 & 2.93 & 1.43 & & & & \\
\hline
\end{tabular}

Hypothesis 1: Mean ratings of male and female pre-service teachers are not significantly different to self-efficacy factors to teaching in affiliate university degree education programme in colleges of education Delta state.

Data in table 4 show t-test summary on mean ratings of male and female on pre-service teachers' self-efficacy factors to teaching. The result shows that male students were 201 with mean rating of 2.91 and $\mathrm{SD}=1.43$ while female students were 252 with mean rating of 2.93 and $\mathrm{SD}=1.43$. The calculated t-value was .088 with $\mathrm{df}=451$ at .05 level of significant and t-critical of \pm 1.96 . Since the $\mathrm{t}$-value of .088 was less than t-critical value of \pm 1.96 at .05 level of significant, the null hypothesis was retained Thus, mean ratings of male and female pre-service teachers is not significantly different to self-efficacy factors to teaching in Delta state.

\section{Results and Discussion}

Findings show that pre-service teachers' perceptions about self-efficacy factors to teaching include; teaching profession is a worthy career, teachers are respectable members of the society, they will take up teaching profession when they graduate, education courses are interesting, they are proud to introduce myself as a would-be teacher, they can encourage someone to take education course as a career, teaching practice is an enjoyable period to me, they are satisfied with the career they going into, the society looks down on teachers, they find my course of study interesting, teaching practice is interesting, teaching profession allows time for private business, the society appreciates teachers, teaching does not provide for professional development of teachers, teachers show laisse faire attitude towards teaching, marking is a difficult moment for me, they teach only when students are prepared to learn, practicum teaching is a waste of time and older teachers show good examples. This view was supported by Adeyemi [14] who observed that many dropouts were victims of hostile school environments, to the extent that many of the students saw the school as a grim joyless place with petty oppressive demands, rules and regulations. Ahmad and Tamiz [12] study on impact of teacher self-efficacy on students' motivation and achievement indicated that there is a positive correlation between teachers' self-efficacy and motivation and achievement of students.

Findings show that measures such as; make students see teaching as part of their daily life, show students the relevance of teaching to their future careers, allow students to participate in the whole process of teaching, use multiple resources in teaching, apply methods that will make teaching fun, relate teaching to real life situation, make learning environment attractive, teach students from simple to complex, understand students interest to the course of study and admit students who have passion for teaching can be used to improve self-efficacy of pre-service teachers to teaching profession. This finding was supported by Protheroe [2] who maintained that, it is not enough to hire and retain the brightest teachers, they must also believe they can successfully meet the challenges of the task at hand. Hence, Lunenburg [5], opined that organizations should select individuals who have high levels of self-efficacy as those people will be motivated to engage in the behaviours that will help them perform well in the workplace. From this point, people with a good measure of self-efficacy should be the ones to be admitted to study teacher education programme. Lunenburg [5] maintained that supervisors can enhance self-efficacy by hiring, providing stimulating assignments, capacity building and coaching, leadership, goal setting, and rewards for enhancement.

Findings show that mean ratings of male and female pre-service teachers are not significant to self-efficacy factors on teaching profession in Delta state. This finding shows that male and female students do not differ on their levels of self-efficacy as an indication that there are different areas that pre-service teachers are capable of handling. The finding is in agreement with the study of Atomatofa [11] which showed that males teachers have positive self-efficacy beliefs about their school climate in their efficiency to influence school resources, instructional self-efficacy, efficacy to influence parental and community participation and efficacy to create a positive learning climate; while the female teachers have positive self-efficacy to influence school resources, influence discipline and influence parental decision. The findings have implication for teacher preparation institutions as regards curriculum planning and pedagogues as well as school managers to supervise teachers and remedy teaching incapability especially for pre-service teachers. The findings of, Sonfo, Amankwah, Sam and Konin [10] that male teachers differ from female teachers in relation to their instructional strategy efficacy beliefs with females having higher instructional efficacy beliefs further support the finding of this study. Tournaki and Podell [13] study on impact of student characteristics and teacher efficacy 
on teachers' predictions of student success conducted on three hundred and eighty-four general education teachers specified that teachers with high efficiency made fewer negative forecasts about students and appeared to adjust their forecasts when student features changed, while little efficacy teachers appeared to be pay attention to single characteristic when casting their predictions. Pendergast, Garvis and Keogh [6] revealed that programme, age and gender were characteristics which were not revealed to be scientifically related to self-efficacy of pre-service participants.

\section{Conclusions}

Conclusively, pre-service teachers exhibited varying levels of self-efficacy in the vocation they would venture into. Self-efficacy is a serious construct in any profession and bearing in mind that education is dealing with impacting ideas into human being and anything wrongly imparted into learners can affect future dispositions of the recipient. The average teacher efficacy showed a figure indicating that pre-service teachers exhibited a good selfefficacy. But the variations in teacher efficacy as showed by the various responses could be worrisome in the educational system bearing in mind the impact of even only one in- efficacious teacher on academic performance of children. One is therefore not surprised that a lot of anomalies happening in the educational system may result from teachers' self-efficacy.

\section{Recommendations/Suggestions}

From the study the following are recommended

1. There should be proper orientation for students with special interest on self-efficacy factors to teaching.

2. Even when students are admitted to study education courses, there should be proper orientation towards the profession by educational managers.

3. The practice of accepting rejected candidates from other departments to study educational courses should not be accepted by faculty of education.

4. Only those who take education as their first choice of course of study should be admitted into teacher education programmes in universities.

\section{Limitations}

This study was conducted in Delta State, Nigeria using only final year Degree students from Colleges of education in Delta State who are affiliated to Delta State University. As such, the students' perception cannot be generalized to all tertiary institutions in Delta in particular and Nigeria in general, thus further study is recommended/suggested for a holistic generalization of the study.

\section{REFERENCES}

[1] A. Bandura. Self-efficacy: The exercise of control. New York: W.H. Freeman, 1997.

[2] N. Protheroe. Teacher Efficacy: What is it and Does It Matter? 2008, https://www.naesp.org/.../1/.../M-Jp42.pd. Accessed June $7^{\text {th }} 2020$.

[3] T. G. Ryan, D. C. Young, W. L. Kraglund-Gauthier. Action Research within Pre-Service Teacher Education, Transformative Dialogues, Teaching \& Learning Journal, Vol. 10, No. 3 pp 1-18, 2017.

[4] J. Mezirow. Transformative Learning as Discourse, Journal of Transformative Education, Vol. 1, No. 1, pp 58-63, 2003.

[5] F. C. Lunenburg. Self- Efficacy in the Workplace: Implications for Motivation and Performance, International Journal of Management, Business, and Administration, Vol. 14, No. 1, pp 1-6, 2014.

[6] D. Pendergast, S. Garvis, J. Keogh. Pre-Service Student-Teacher Self-Efficacy Beliefs: An Insight into the Making of Teachers, Australian Journal of Teacher Education, Vol. 36 No. 12, pp 46-58, 2011.

[7] M. A, Dahar, R. A. Dahar, R. T. Dahar, F. A. Faize. Impact of Teacher Quality on the Academic Achievement of Student at Secondary Stage in Punjab (Pakistan), European Journal of Social Sciences, Vol. 19 No. 1, pp 97-105, 2011.

[8] [8] A. Bandura. Self-efficacy, Encyclopaedia of human behaviour, Vol. 4, pp 71-81, 1994.

[9] [9] D. H. Lindquist, C. Y. Lindquist. Challenging Pre-service Teachers' Perceptions of the Profession: Applying Breakthrough Thinking in Teacher Preparation Programs, Scholarlypartnershipsedu Vol. 3 No. 1, p 8, 2008.

[10] F. Sonfo, F. Amankwhah, F. Sam, D. Konin. Teachers self-efficacy beliefs: The relationship between gender and instructional strategies classroom management and student engagement, Ghana Journal of Development Studies, Vol. 12 No. 1\&2, pp 19-31, 2015.

[11] [R. O. Atomatofa. Pre-service science teachers, gender, and self-efficacy beliefs about school climate in Nigeria, Tropical Journal of Education, Vol. 1 No. 1/2, pp 1 - 13, 2019.

[12] M. Ahmad, M. P. Tamiz. The Impact of Teacher Self-efficacy on the Students' Motivation and Achievement, Theory and Practice in Language Studies, Vol. 2, No. 3, pp 483-491, 2012.

[13] N. Tournaki, D. Podell. The impact of student characteristics and teacher efficacy on teachers' predictions of student success, Teaching and Teacher Education, Vol. 21, No 3, pp 299-314, 2005.

[14] J. K. Adeyemi. Analysis of wastage rate in public primary schools in former Oredo L.G.A of Edo State, Benin Journal of Education, Vol. 1 No. 2, pp 1-8, 1998.

[15] A. Bandura. Social cognitive theory in cultural context, Journal of Applied Psychology: An international Review, Vol. 51, pp 269-290, 2002. 